
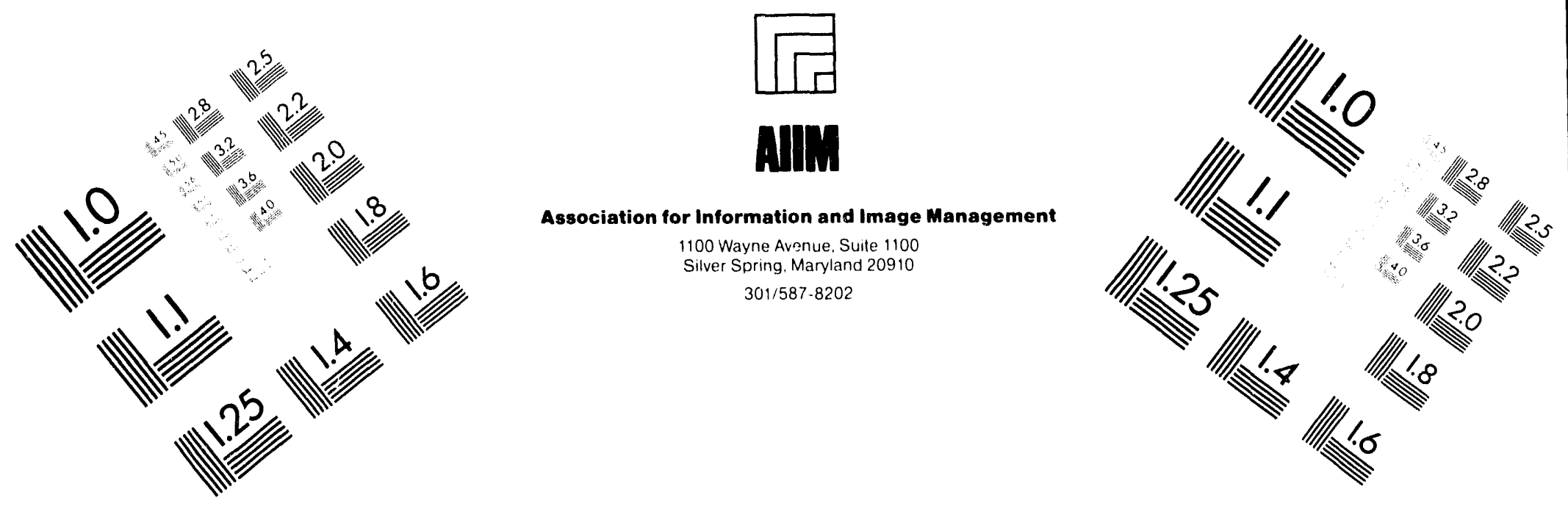

\title{
Centimeter
}

$\begin{array}{llllllllllllllll}1 & 2 & 3 & 4 & 5 & 6 & 7 & 8 & 9 & 10 & 11 & 12 & 13 & 14 & 15 & \mathrm{~mm}\end{array}$

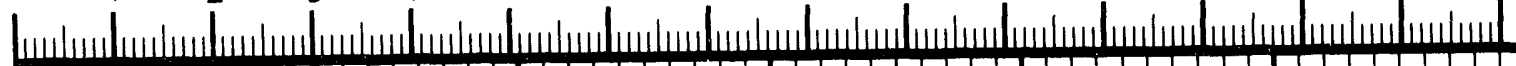

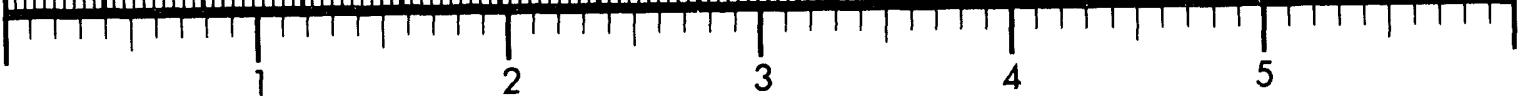
Inches
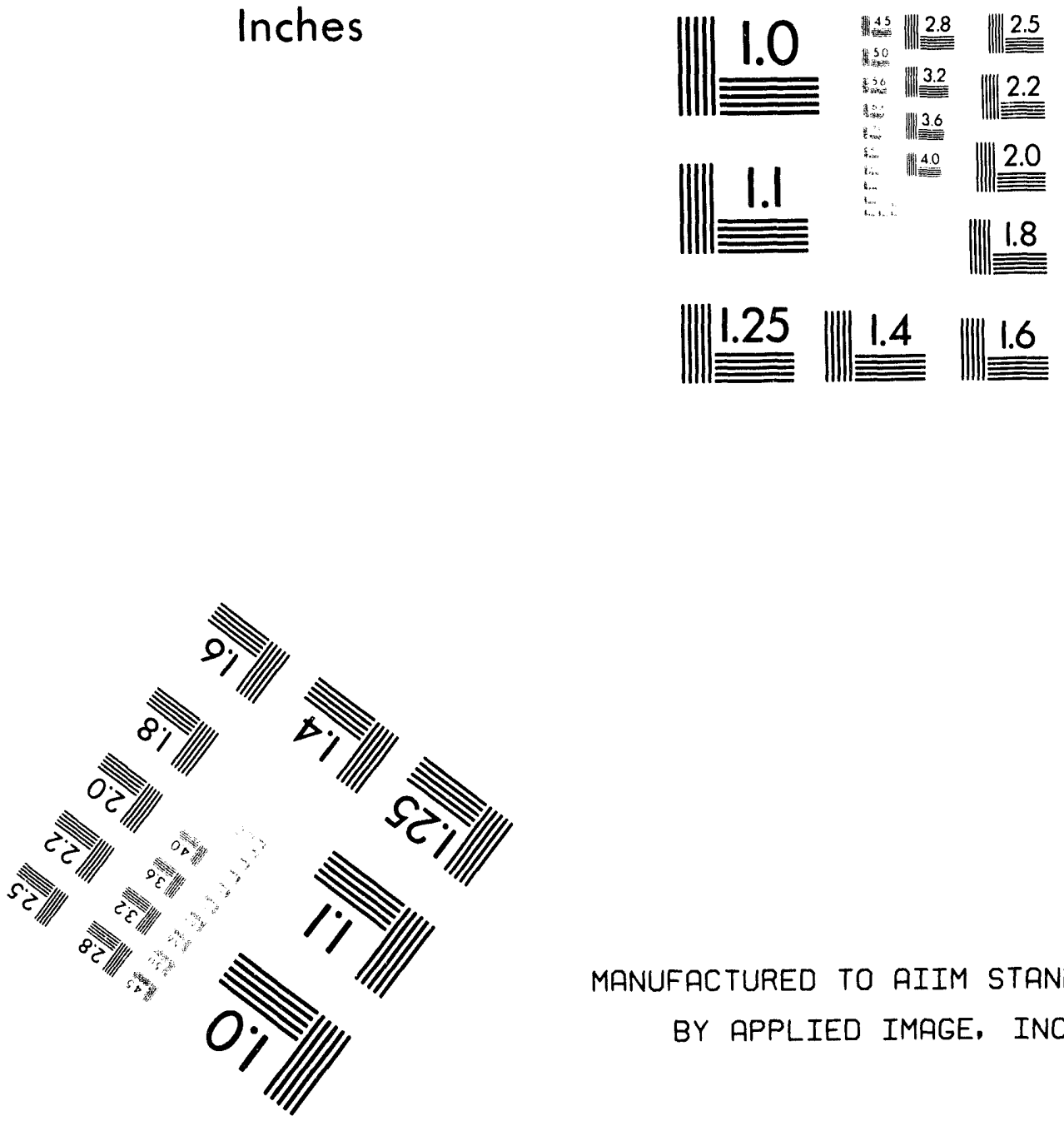

MANUFACTURED TO AIIM STANDARDS

BY APPLIED IMAGE, INC.

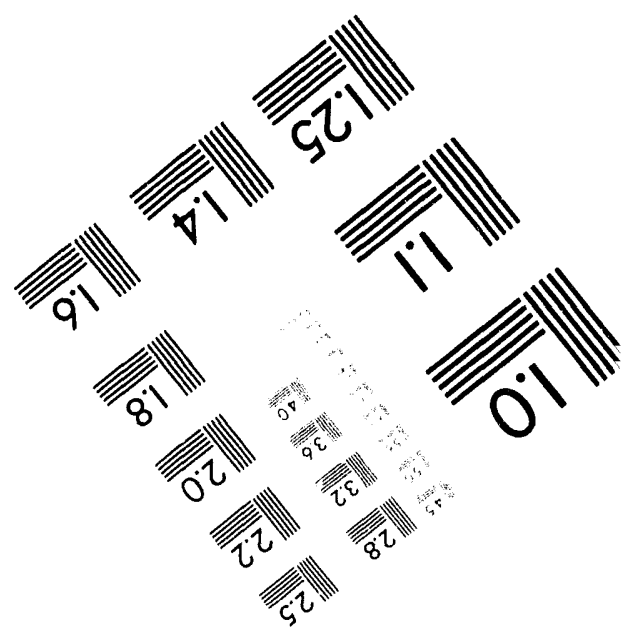





\section{Mixed Waste Management Facility}

Monthly Report

February 1994

Ronald D. Streit

March 1994

LAWRENCE LIVERMORE NATIONAL LABORATORY

University of California $\bullet$ Livermore, California $\bullet 94550$ 


\section{Summary}

During February, significant progress was made toward the completion of the Conceptual Design (CD), particularly in developing a methodology and process for estimating CD costs and providing roll-up information in preparing the $\mathrm{CD}$. As a result of this effort, a number of changes to the WBS were instituted to ensure that all key elements of the roll-up can be identified. Using the revised WBS, a bottom-up cost estimation for the CD was initiated, and an integrated schedule was developed. System Design Requirements and process flowsheets were frozen and placed under formal change control. An integrated project schedule was completed, including key project linkages between process engineering, permitting, B494 upgrade, and operations planning activities. Work also began to update the detailed PERT/critical-path schedule to reflect current $C D$ plans.

As a result of a number of DOE informal reviews during January and February, additional Project guidance was received for the preparation of several project documents and supporting information on the historical funding and manpower expenditures relative to identified milestones and markers. Documentation requested included the Technology Selection Plan for Primary Processes (Milestone 115-5) and reports and briefings addressing the implementation of Molten Salt Oxidation (MSO). A draft joint LLNL/ORNL Plan for the Demonstration and Deployment of the MSO Process was developed along with documentation for the resolution of MSO issues identified in the December 1993 MSO Technical Review.

On February 25, DOE/OAK issued re rised funding guidance and funds to maintain expenditure levels at the January level and to complete work on the Conceptual Design and ES\&H evaluation activities. This represents a decrease of $\$ 1487 \mathrm{~K}$ through April in combined OPEX and CENRTC, and will result in the deference of some project milestones and markers identified in the MWMF FY94 Plan, issued January 1994. As the guidance was issued during the month, cost "redirection" was only partially completed. In addition, the funding released by DOE/OAK does not have the balance between OPEX and CENRTC as defined in the FY94 Plan, so that certain CENRTC accounts cannot yet be opened; this is under discussion with DOE/OAK for resolution.

The following list summarizes significant accomplishments in February:

- Internal reviews of the draft PSAR and EA were completed.

- The Technology Selection and Implementation Plan Part I: Primary Processes was issued.

- Draft joint LLNL/ORNL Plan for the Demonstration and Deployment of the MSO Process was completed.

- The System Design Requirements and process flowsheets were frozen and placed under formal change control.

- An integrated project schedule was completed, including key project linkages between process engineering, permitting, B494 upgrade, and operations planning activities. Work also began to update the detailed PERT/critical-path schedule to reflect current CD plans.

- A bottom-up cost estimation for the CDR was begun.

- Measurements of silver recovery yield at various hydroxide concentrations for Mediated Electrochemical Oxidation (MEO) were completed.

- Waste dispersion measurements were completed in support of the Wet Oxidation process design.

- Evaluation of commercial front-end processors and supervisory control systems continued, with several on-site vendor discussions and demonstrations being held. 


\section{Project Financial Summary}

Based on LLNL cost reports through February, 1994, the total spending rate for February was somewhat below th: original spending plan, but above the January rate (since the revised guidance was not issued until February 25). Efforts are being made to reduce spending to meet the revised guidance. The proper split of OPEX and CENRTC funds is also being addressed with DOE/OAK.

OPEX (\$K), cumulative:

\begin{tabular}{|r|r|r|l|l|l|l|l|l|l|l|l|l|}
\hline & Oct & Nov & Dec & Jan & Feb & Mar & Apr & May & Jun & Jul & Aug & Sep \\
\hline Plan & 425 & 820 & 1231 & 1628 & 2039 & 2423 & 2539 & 2655 & 2766 & 2905 & 3044 & 3160 \\
\hline Rev. Plan** & 425 & 820 & 1231 & 1628 & 2076 & 2506 & 2945 & & & & & \\
\hline Actual & 491 & 847 & 1299 & 1739 & 2232 & & & & & & & \\
\hline Funding & $680^{*}$ & 680 & 1630 & 1630 & 3103 & & & & & & & \\
\hline
\end{tabular}

CENRTC (\$K), cumulative:

\begin{tabular}{|r|r|r|r|r|r|r|r|r|r|r|r|c|}
\hline & Oct & Nov & Dec & Jan & Feb & Mar & Apr & May & Jun & Jul & Aug & Sep \\
\hline Plan & 148 & 273 & 416 & 593 & 846 & 1417 & 2154 & 3147 & 4087 & 5000 & 6332 & 7620 \\
\hline Rev. Plan** & 148 & 273 & 416 & 593 & 753 & 913 & 1073 & & & & & \\
\hline Actual & 156 & 275 & 407 & 538 & 676 & & & & & & & \\
\hline \hline Funding & $370^{*}$ & 370 & 470 & 470 & 870 & & & & & & & \\
\hline
\end{tabular}

* FY93 carry-over

** Revised Plan represents funding guidance through April from DOE/OAK (letter, K. King to R. Streit, received Feb. 25, 1994) 
February 1994

\section{Contents}

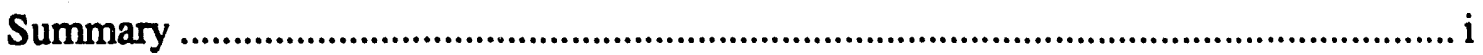

Project Financial Summary ....................................................................................... ii

1.1.1. Quality Assurance .......................................................................................... 1

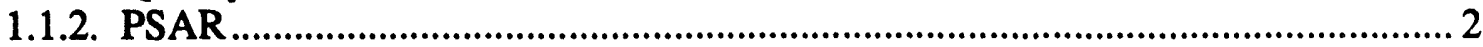

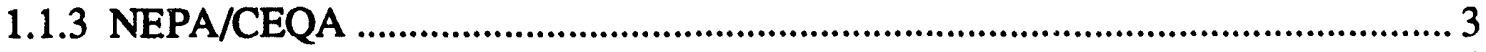

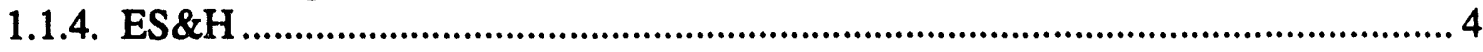

1.1.5. Program Support ............................................................................................... 5

1.1.6. Public Participation ............................................................................................

1.2.1. Conceptual Design .................................................................................................. 8

1.2.2. Plant Start-Up Management ................................................................................. 9

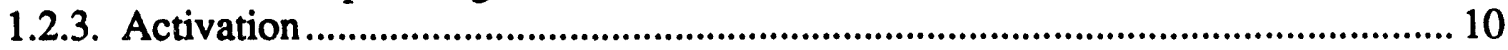

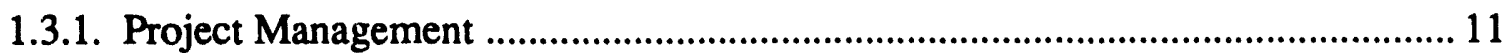

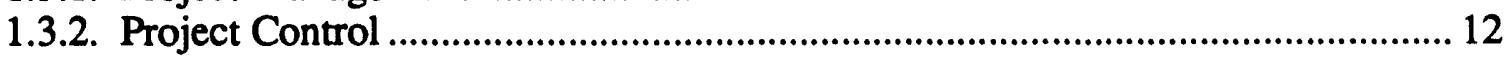

1.3.3. Technical Systems Integration ............................................................................. 13

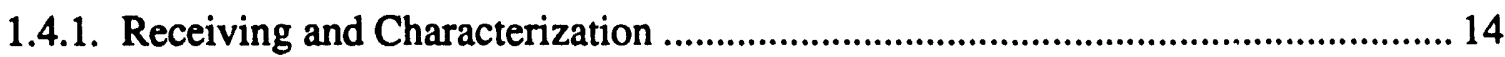

1.4.2. Solids Feed Preparation ...................................................................................... 15

1.4.3. Liquids Feed Preparation ................................................................................. 16

1.5.1. Mediated Electrochemical Oxidation................................................................ 17

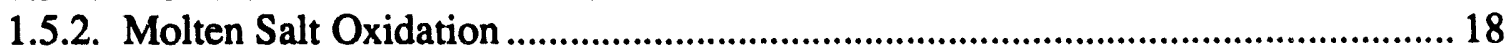

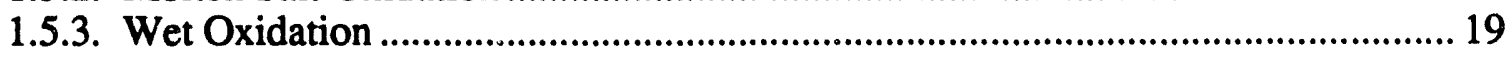

1.5.4. Ultraviolet Photolysis........................................................................................... 20

1.5.5. Experimental Off-Gas ........................................................................................ 21

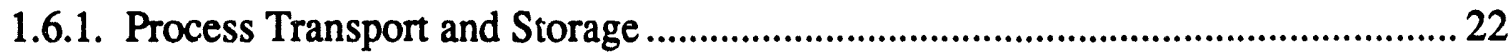

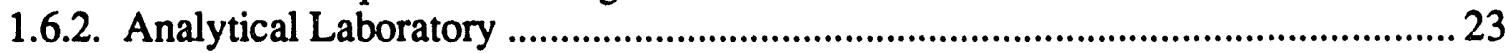

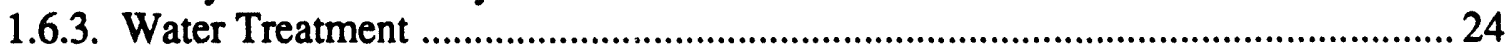

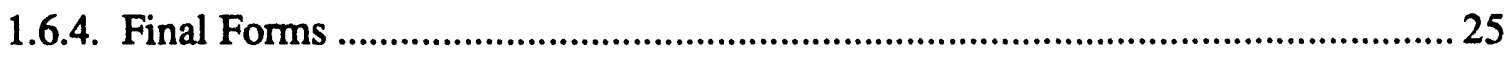

1.6.5. Supervisory Instrumentation and Control ......................................................... 26 
UCRL-ID-116187-94-2

MWMF Monthly Report Summary

February 1994 
February 1994

\section{WBS Element: 1.1.1. Quality Assurance}

\section{Task Description:}

Quality Assurance provides quality assurance and safeguards support for and evaluations of the MWMF Project to ensure compliance with applicable DOE regulations, and environmental, safety, health, and NEPA/CEQA requirements. This effort includes development of the project's quality assurance documentation and oversight for conformance to the approved plan.

\section{Summary of Activities:}

The QA Manager briefed the MWMF Steering Committee on the document control system. He also generated a 4th Dimension database tracking system for tracking of Project-level action items.

Cost Summary: $\quad$ FY94 Budget: \$180K OPEX

\begin{tabular}{|r|r|r|r|r|r|r|r|r|r|r|r|r|}
\hline & Oct & Nov & Dec & Jan & Feb & Mar & Apr & May & Jun & Jul & Aug & Sep \\
\hline Plan & 9 & 11 & 11 & 13 & 15 & 16 & 17 & 17 & 17 & 18 & 18 & 18 \\
\hline Actual & 11 & 11 & 8 & 6 & 3 & & & & & & & \\
\hline
\end{tabular}

FY94 Major Procurements:

None

Key Milestones and Markers:

\begin{tabular}{llcl} 
& Item & $\begin{array}{c}\text { Scheduled } \\
\text { Dat: }\end{array}$ & Status \\
\hline L111-1 & Develop and issue Quality Assurance Plan & Oct $\sqrt[93]{3}$ & Complete \\
L111-2 & Develop and issue Document Control Plan & Jan 94 & Complete
\end{tabular}




\section{WBS Element: $\quad$ 1.1.2. PSAR}

\section{Task Description:}

The PSAR provides the integration of safety input, design reviews, and safety analysis for the MWMF Preliminary Safety Analysis Report (PSAR). Safety analysis includes the analysis, generation of documentation, and documentation review and approval. The element includes the generation of the Preliminary Safety Analysis Report and follow-on analysis required prior to the generation of the Final Safety Analysis Report (FSAR). This element provides additional criticality support to resolve safety issues.

\section{Summary of Activities:}

The first draft of the PSAR was reviewed by LLNL staff and comments collected into an electronic database for tracking. Due to the need to coordinate information with the Conceptual Design Report, delivery of the final PSAR has been delayed by approximately one month. This is not anticipated to have an impact on the overall project schedule.

Cost Summary: FY94 Budget: \$230K OPEX

\begin{tabular}{|r|r|r|r|r|r|r|r|r|r|r|r|r|}
\hline & Oct & Nov & Dec & Jan & Feb & Mar & Apr & May & Jun & Jul & Aug & Sep \\
\hline Plan & 59 & 57 & 50 & 31 & 22 & 11 & 0 & 0 & 0 & 0 & 0 & 0 \\
\hline Actual & 30 & 9 & 10 & 2 & 24 & & & & & & & \\
\hline
\end{tabular}

FY94 Major Procurements:

Contract for services to prepare Safety Analysis Report: $\$ 205 \mathrm{~K}$

Key Milestones and Markers:

\begin{tabular}{llcl} 
& Item & $\begin{array}{c}\text { Scheduled } \\
\text { Date }\end{array}$ & Status \\
\hline L112-1.1 & Issue Contract & Oct 93 & Complete \\
L112-1.2 & Preliminary PSAR Review & Feb 94 & Complete \\
L112-1 & PSAR to DOE for Review & Apr 94(1) & Open \\
D112-1 & PSAR Approved by DOE & Jul 94 (2) & Open
\end{tabular}

(1) Revised from March 94 (discussed above)

(2) Revised from June 94 (discussed above) 


\section{February 1994}

\section{WRS Element: $\quad$ 1.1.3 NEPA/CEQA}

Task Description:

NEPA/CEQA provides for the preparation of input to the Environmental Assessment (EA) and all required follow-up documentation required for the NEPA/CEQA and necessary permitting. The effort includes preliminary evaluations, preparation of an implementation plan, preparation of technical information to support EA preparation, and comment resolution. This element prepares and coordinates approval of State, EPA, and local permits and supports public participation activities associated with the permits approvals.

\section{Summary of Activities:}

The draft Environmental Assessment continues to be revised to make changes identified by internal review cycles and to reflect additional details on accident analyses provided in the Preliminary Hazards Analysis and PSAR documents.

The RD\&D permit application was outlined for distribution to the MWMF Steering committee members showing specific information and level of detail needed in each section. Staff are investigating methodologies of how to satifactorily demonstrate equivalency to Land Disposal Restriction treatment technology standards.

The preparation of air permits for the Bay Area Air Quality Management District will begin upon completion of the CDR. Initial contact with the air district has taken place to reduce the possibility of delays.

Cost Summary: FY94 Budget: \$290K OPEX

\begin{tabular}{|r|r|r|r|r|r|r|r|r|r|r|r|r|}
\hline & Oct & Nov & Dec & Jan & Feb & Mar & Apr & May & Jun & Jul & Aug & Sep \\
\hline \hline Plan & 9 & 12 & 36 & 36 & 37 & 21 & 18 & 18 & 13 & 39 & 39 & 12 \\
\hline Actual & 8 & 10 & 29 & 11 & 13 & & & & & & & \\
\hline
\end{tabular}

FY94 Major Procurements:

None

Key Milestones and Markers:

\begin{tabular}{llcl} 
& Item & Scheduled \\
& Date & Status \\
\hline L113-1 & Environmental Assessment (EA) submitted to DOE & Mar 94 & Open \\
D113-1 & EA approved by DOE & Aug 94 & Open \\
L113-2 & Air permit application submitted to BAAQMD & May 94 & Open \\
L113-3 & $\begin{array}{l}\text { Research, Development \& Demonstration (RD\&D) permit } \\
\text { application submitted to DTSC }\end{array}$ & Jul 94 & Open \\
C113-2 & Authority to Construct issued by BAAQMD & Oct 94 & Open
\end{tabular}




\section{WBS Element: $\quad$ 1.1.4. ES\&H}

Task Description:

ES\&H provides for Environment, Safety, and Health representation to the MWMF project to ensure that all activities are conducted in a safe and environmentally sound manner and to ensure that ES\&H standards have been properly applied. This element provides for conducting and/or monitoring safety-related analyses and the resultant documentation. Specific activities include preparing and implementing various assurance plans; performing hazard evaluations and safety assessments; participating in design reviews to ensure compliance with safety and environmental standards and regulations; preparing safety and environmental procedures; and preparing input for permit applications and other documentation required for compliance with Federal and/or State requirements.

\section{Summary of Activities:}

Members of the ES\&H team have continued attending technical meetings and consulting with principal investigators and engineers on ES\&H issues. More time has been spent by members of the ES\&H team reviewing the PSAR.

Cost Summary: FY94 Budget: \$120K OPEX

\begin{tabular}{|r|r|r|r|r|r|r|r|r|r|r|r|r|}
\hline & Oct & Nov & Dec & Jan & Feb & Mar & Apr & May & Jun & Jul & Aug & Sep \\
\hline Plan & 8 & 8 & 8 & 8 & 9 & 9 & 9 & 12 & 12 & 12 & 12 & 13 \\
\hline Actual & 2 & 10 & 12 & 13 & 16 & & & & & & & \\
\hline
\end{tabular}

FY94 Major Procurements:

None

Key Milestones and Markers:

\begin{tabular}{llcl} 
& Item & $\begin{array}{c}\text { Scheduled } \\
\text { Date }\end{array}$ & Status \\
\hline $114-1.1$ & Review of 30\% Conceptual Design & Dec 93 & Complete \\
$114-1.2$ & Review of 90\% Conceptual Design & Mar 94 & Open \\
$114-1.3$ & Review 90\% Preliminary Design & Sep 94 & Open
\end{tabular}


February 1994

\section{WBS Element: $\quad$ 1.1.5. Program Support}

\section{Task Description:}

Program Support provides top-level planning, control, and support of MWMF project OPEXfunded activities. Specific activities include management of project assurances and interface with development activities. This element encompasses support for the Project Office, including organization, schedule and budgeting activities, project plans and reporting, personnel hiring and housing, project operations control, Building 494 occupant relocation, and OPEX-funded technical support.

\section{Summary of Activities:}

During February a number of reviews of the MWMF were conducted. As a result, additional guidance was recieved from DOE for the preparation of several Project documents and supporting information on the historical funding and manpower expenditures relative to identified milestones and markers. Documentation requested included the Technology Selection Plan (Milestone 115-5) and reports and briefings addressing the implementation of Molten Salt Oxidation (MSO). A draft joint LLNL/ORNL Plan for the Demonstration and Deployment of the MSO Process was developed along with documentation for the resolution of MSO issues identified in the December 1993 MSO Technical Review. These documents (in draft form) are being prepared for a briefing to DOE during March 1994. Specific activities of significance are listed below:

- System Design Requirements and process flowsheets were frozen and placed under formal change control.

- An integrated project schedule was completed, including key project linkages between process engineering, permitting, B494 upgrade, and operations planning activities. Work also began updating the detailed PERT/critical-path schedule to reflect current CD plans.

- Responded to IG Survey requests for information on DWTF and MWMF

- Documents and briefing being developed

- Technology Selection and Implementaion Plan: Part 1 Primary Processes (Completed);

- Joint LLNL/ORNL Plan for the Demonstation and Deployment of the MSO Process;

- Technical Plan for the Resolution of Outstanding MSO Issues;

- EM-50 TTP for MSO Expedited Demonstration in support of Joint LLNL/ORNL Plan;

- Information package in support of EM-30 MWMF Decision Briefing (5 support briefings).

- Activities regarding safety and environmental analyses and hazard classfication of the MWMF were supported. After meeting with DOE/OAK, it is the Project's understanding that the "below Category 3" radiological classification is supported by the local field office; however, no formal response has yet been received.

- Processes to control several Project baselines were established, but are reported under WBS 1.3.2.

- The PTS and January Monthly Reports were issued to DOE.

Cost Summary: FY94 Budget: \$1250K OPEX

(NOTE: revised actual costs reflect revised cost data.)

\begin{tabular}{|r|r|r|r|r|r|r|r|r|r|r|r|r|}
\hline & Oct & Nov & Dec & Jan & Feb & Mar & Apr & May & Jun & Jul & Aug & Sep \\
\hline \hline Plan & 230 & 157 & 151 & 145 & 122 & 121 & 56 & 53 & 53 & 53 & 53 & 56 \\
\hline Actual & 331 & 161 & 192 & 135 & 191 & & & & & & & \\
\hline
\end{tabular}


The increased charges in February were a result of two factors:

1. Delayed DOE funds for CENRTC. Costs transfers should correct this during the next month.

2. Unscheduled Project reviews and documentation on the implementation of MSO technology as identified in discussion above.

Key Milestones and Markers:

Item $\begin{gathered}\text { Scheduled } \\ \text { Date }\end{gathered}$ Status

L115-1.1 Project Management Plan (Draft)

Oct 93 Complete

L115-2 Select Project Engineers and Project Control Manager

L115-3 Submit FY94 Project Plan

L115-4 Initiate PTS and Monthly reporting

Dec 93

Complete

Jan 94 Complete

Jan 94

Complete

L115-5 Technology Selection and Implementation Plan, Part I: Feb 94

Complete

L115-6 Develop Design Basis Operations Plan

Mar 94 In Process

L115-1 Project Management Plan (Final)

Apr 94

Open

L115-7

Submit FY95 Project Plan (OPEX)

Sep 94

Open 


\section{WBS Element: 1.1.6. Public Participation}

Task Description:

Public Participation provides for public input to the planning and execution phases of the MWMF project. Included are a National Advisory Committee, a Community Newsletter and preparation and coordination of press releases and community tours.

\section{Summary of Activities:}

This activity is on hold by Project due to DOE revised funding guidance. January charges represent a prior lein.

Cost Summary: $\quad$ FY94 Budget: \$150K OPEX

\begin{tabular}{|r|r|r|r|r|r|r|r|r|r|r|r|r|}
\hline & Oct & Nov & Dec & Jan & Feb & Mar & Apr & May & Jun & Jul & Aug & Sep \\
\hline Plan & 0 & 0 & 5 & 14 & 16 & 16 & 16 & 16 & 16 & 17 & 17 & 17 \\
\hline Actual & 0 & 1 & 0 & 4 & 0 & & & & & & & \\
\hline
\end{tabular}

FY94 Major Procurements:

Contracted support for Public Participation activities

Key Milestones and Markers:

\begin{tabular}{llcl}
\hline L116-1.1 & National Advisory Committee (NAC) formed & Feb 94 & On Hold \\
L116-2.1 & Issue first public newsletter & Mar 94 & On Hold \\
L116-1.2 & First meeting of NAC & Mar 94 & Open \\
L116-1.3 & Receive comments on CDR Draft fron: NAC & Apr 94 & Open \\
L116-2.2 & Issue second newsletter & Jun 94 & Open \\
L116-1.4 & Second meeting of NAC & Jul 94 & Open \\
L116-2.3 & Issue third newsletter & Sep 94 & Open
\end{tabular}

(1) All activities on hold to accommodate reduced DOE funding guidance. Dates will be revised upon longer-term DOE funding guidance; see "Summary." 
WBS Element: $\quad$ 1.2.1. Conceptual Design

Task Description:

Conceptual Design provides the project's technical, cost, and schedule baselines that form the basis for KD-1.

\section{Suminary of Activities:}

Conceptual system and equipment designs and general management were completed. Process flow diagrams were updated to reflect the CDR baseline waste stream. Preparation of the cost estimate and integrated schedule was initiated. The first rollup of these CDR elements is targeted for early March.

Cost Summary: $\quad$ FY94 Budget: \$940K OPEX

\begin{tabular}{|r|r|r|r|r|r|r|r|r|r|r|r|r|}
\hline & Oct & Nov & Dec & Jan & Feb & Mar & Apr & May & Jun & Jul & Aug & Sep \\
\hline Plan & 110 & 150 & 150 & 150 & 190 & 190 & 0 & 0 & 0 & 0 & 0 & 0 \\
\hline Actual & 111 & 154 & 198 & 268 & 250 & & & & & & & \\
\hline
\end{tabular}

FY94 Major Procurements:

Contracted services for CDR support: \$7K

(Corrected January CDR services, listed as $\$ 40 \mathrm{~K}$ : \$13K)

Key Milestones and Markers:

\begin{tabular}{llcl} 
& Item & Scheduled & \\
Date & Status \\
\hline L121-1.1 & Initiate Point Design Reviews & Oct 93 & Complete \\
L121-1.2 & Complete Point Design Reviews & Nov 93 & Complete \\
L121-1 & 30\% CDR Review & Dec 93 & Complete \\
L121-2 & 90\% CDR Review & Mar 94 & Open \\
L121-3 & Conceptual Design Review issued & Apr 94 & Open \\
D121-1 & Preliminary Approval and Funding to proceed & Apr 94 & Open \\
& into PD & & \\
D121-2 & KD-1/2 Decision approved DOE & Jun 94 & Open
\end{tabular}




\section{WBS Element: $\quad$ 1.2.2. Plant Start-Up Management}

Task Description:

Plant Start-Up Management provides (1) operations and maintenance review of system designs, (2) the development of top-level plans for staffing, training, testing, and readiness review, (3) task analysis and preparation, review, and revision of site operating plan, maintenance, instrument calibration, and emergency response procedures, (4) recruiting, hiring, clearing, and providing general employee training for the plant staff, and (5) the development of training materials, training the trainers, and special technical and on-the-job training for the plant staff.

Summary of Activities:

No activities are scheduled for this WBS element for FY94.

Cost Summary:: FY94 Budget: \$OK OPEX

\begin{tabular}{|r|r|r|r|r|r|r|r|r|r|r|r|r|}
\hline & Oct & Nov & Dec & Jan & Feb & Mar & Apr & May & Jun & Jul & Aug & Sep \\
\hline Plan & 0 & 0 & 0 & 0 & 0 & 0 & 0 & 0 & 0 & 0 & 0 & 0 \\
\hline Actual & 0 & 0 & 0 & 0 & 0 & & & & & & & \\
\hline
\end{tabular}

FY94 Major Procurements:

None

Key Milestones and Markers:

Item $\begin{array}{cc}\text { Scheduled } \\ \text { Date }\end{array}$ Status

None 


\section{WBS Element: 1.2.3. Activation}

Task Description:

Activation provides (1) the preparation, review, revision, and release of all Operational Test Procedures (OTPs); (2) plant systems activation, integration, and performance of Operational Test Procedures in each of the technology areas including Operational Readiness Reviews; (3) technical support for the preparation of Operational Safety Requirements (OSR) and Facility Safety Requirements (FSR), the identification and resolution of problems during plant operational testing, start-up, and activation, including finalization of design documentation for equipment and process modifications; (4) maintenance support to perform equipment or process modifications during start-up, testing, and activation; (5) all operational spares and the initial stores inventory; and (6) all manpower and materials required to deliver support services (e.g., utilities, power, etc.) during construction, testing, and activation of the MWMF.

\section{Summary of Activities:}

No activities are scheduled for this WBS element for FY94.

Cost Summary: FY94 Budget: \$OK OPEX

\begin{tabular}{|r|r|r|r|r|r|r|r|r|r|r|r|r|}
\hline & Oct & Nov & Dec & Jan & Feb & Mar & Apr & May & Jun & Jul & Aug & Sep \\
\hline Plan & 0 & 0 & 0 & 0 & 0 & 0 & 0 & 0 & 0 & 0 & 0 & 0 \\
\hline Actual & 0 & 0 & 0 & 0 & 0 & & & & & & & \\
\hline
\end{tabular}

FY94 Major Procurements:

None

Key Milestones and Markers:

Item $\begin{gathered}\text { Scheduled } \\ \text { Date }\end{gathered}$

None 


\section{February 1994}

\section{WBS Element: $\quad$ 1.3.1. Project Management}

Task Description:

Project Management provides top-level project planning, direction, and control of the MWMF project's CENRTC-funded systems. Specific activities include project management and support of Project Office, project assurance (including quality assurance, safeguards, environmental, and safety oversight), management overview of information management and technical activities, and interface with DOE.

Summary of Activities:

No activities for this reporting period.

Cost Summary: $\quad$ FY94 Budget: \$300K CENRTC

\begin{tabular}{|r|r|r|r|r|r|r|r|r|r|r|r|r|}
\hline & Oct & Nov & Dec & Jan & Feb & Mar & Apr & May & Jun & Jul & Aug & Sep \\
\hline Plan & 0 & 0 & 0 & 0 & 0 & 0 & 50 & 50 & 50 & 50 & 50 & 50 \\
\hline Actual & 0 & 0 & 0 & 0 & 0 & & & & & & & \\
\hline
\end{tabular}

FY94 Major Procurements:

Service contract to SAIC for project support and independent technical and administrative reviews.

Key Milestones and Markers:

Item

Scheduled

Date

Status

L131-1.1 In-house Point Design Review

L131-1 90\% Preliminary Design Review(1)

Jun 94

Sep 94

Open

L131-2 Submit FY95 Project Plan (CENRTC)

Sep 94

Open

Open

(1) Tied to April 1st KD-1/2 decision approval from DOE. 


\section{WBS Element: $\quad$ 1.3.2. Project Control}

Task Description:

Project Control provides for the project integration, configuration management, cost and schedule control, and administration of the CENRTC-funded systems. Develops and maintains the management systems used to monitor progress against the established baselines and to ensure configuration control (drawings, documents, etc.).

Summary of Activities:

Due to restricted funding guidance from DOE, only essential activities that are required for the control of important Project baselines were initiated during February under this WBS.

Mechanisms and processes to control baseline Project design criteria, organization (WBS, etc.), documents, and cost/schedule were instituted, but not yet formally documented. Due to funding changes, it is estimated that the formal Configuration Control Plan will be issued in May, 1994. The lack of charges in February was due to delayed DOE funds for CENRTC (see "Summary"). Costs transfers should correct this during the next month.

Cost Summary: $\quad$ FY94 Budget: \$300K CENRTC

\begin{tabular}{|r|r|r|r|r|r|r|r|r|r|r|r|r|}
\hline & Oct & Nov & Dec & Jan & Feb & Mar & Apr & May & Jun & Jul & Aug & Sep \\
\hline \hline Plan & 0 & 0 & 0 & 0 & 28 & 34 & 39 & 39 & 44 & 38 & 39 & 39 \\
\hline Actual & 0 & 0 & 0 & 0 & 0 & & & & & & & \\
\hline
\end{tabular}

FY94 Major Procurements:

None

Key Milestones and Markers:

\begin{tabular}{llcl} 
& Item & $\begin{array}{c}\text { Scheduled } \\
\text { Date }^{(1)}\end{array}$ & Status \\
\hline L132-2.1 & Prepare Configuration Control Plan & May 94(2) & In progress \\
L132-2.2 & Prepare Design Review Procedure & Mar 94 & Open \\
L132-1 & Implement cost planning/tracking systems & June 94 & Open \\
L132-2 & Implement technical baseline control system & May 94 & Open \\
L132-3 & Implement schedule control/tracking system & Aug 94 & Open
\end{tabular}

(1) All except essential activities deferred to accommodate reduced DOE funding guidance. Dates will be revised upon longer-term DOE funding guidance; see "Summary."

(2) Revised from February 94; see discussion above. 


\section{February 1994}

\section{WBS Element: $\quad$ 1.3.3. Technical Systems Integration}

Task Description:

Technical Systems Integration provides the oversight and performance studies intended to verify or document system integration performance, system analysis, special process diagnostics, and planning and analysis of the process aspects of integrated tests. It also includes the responsibility for assuring that the systems aspects of the overall processes are adequately addressed in the integrated design. Includes System Engineering Management Plan and System Design Requirements coordination. Specific topics include the integration of waste-treatment processes and facility, risk assessment, accountability, safety, radiation exposure, and availability.

\section{Summary of Activities:}

No activities for this reporting period.

Cost Summary: FY94 Budget: \$300K CENRTC

\begin{tabular}{|r|r|r|r|r|r|r|r|r|r|r|r|r|}
\hline & Oct & Nov & Dec & Jan & Feb & Mar & Apr & May & Jun & Jul & Aug & Sep \\
\hline Plan & 0 & 0 & 0 & 0 & 0 & 0 & 50 & 50 & 50 & 50 & 50 & 50 \\
\hline Actual & 0 & 0 & 0 & 0 & 0 & & & & & & & \\
\hline
\end{tabular}

FY94 Major Procurements:

None

Key Milestones and Markers:

\begin{tabular}{llcc} 
& Scheduled & \\
& Item & Date & Status \\
\hline L133-1.1 & Draft System Engineering Management Plan & Sep 94 & Open
\end{tabular}


WBS Element: 1.4.1. Receiving and Characterization

\section{Task Description:}

The principal objective of the Receiving and Characterization system is to provide for the receiving, logging, identification and characterization of all incoming we te containers and to determine the acceptability for processing the waste. Receiving and Characterization provides the management, system analysis and support, design (Title I, II, III) engineering, procurement, installation of Receiving and Characterization equipment, Title III inspection, and acceptance test procedures (ATP). Receiving and Characterization includes both receiving and characterization equipment and systems integration.

\section{Summary of Activities:}

No activities for this reporting period.

Cost Summary: FY94 Budget: \$200K CENRTC

\begin{tabular}{|r|r|r|r|r|r|r|r|r|r|r|r|r|}
\hline & Oct & Nov & Dec & Jan & Feb & Mar & Apr & May & Jun & Jul & Aug & Sep \\
\hline Plan & 0 & 0 & 0 & 0 & 0 & 20 & 30 & 30 & 30 & 30 & 30 & 30 \\
\hline Actual & 0 & 0 & 0 & 0 & 0 & & & & & & & \\
\hline
\end{tabular}

FY94 Major Procurements:

None

Key Milestones and Markers:

\begin{tabular}{llll} 
& Item & $\begin{array}{c}\text { Scheduled } \\
\text { Date }\end{array}$ & Status \\
\hline L141-1.1 & Pilot characterization studies complete & Jun 94 & Open \\
L141-1.2 & Equipment identified and floor plan defined & Sep 94 & Open \\
L141-1 & 90\% Preliminary Design Review & Sep 94 & Open
\end{tabular}


February 1994

\section{WBS Element: $\quad$ 1.4.2. Solids Feed Preparation}

\section{Task Description:}

The principal objective of the Solids Feed Preparation system is to provide for the receipt, characterization, preparation for processing, and handling of homogeneous and heterogeneous solids received from storage and other processes in the facility. This includes segregating the incoming waste stream into combustible solids, heterogeneous solids, homogeneous inorganic solids and metals, and liquids that were not previously identified. Solids Feed Preparation provides the management, system analysis and support, design (Title I, II, III) engineering, procurement, installation of Solids Feed Preparation equipment, Title III inspection, and acceptance test procedures (ATP). Solids Feed Preparation includes both solids feed preparation equipment and systems integration.

\section{Summary of Activities:}

No activities for this reporting period.

Cost Summary: FY94 Budget: \$600K CENRTC

\begin{tabular}{|r|r|r|r|r|r|r|r|r|r|r|r|r|}
\hline & Oct & Nov & Dec & Jan & Feb & Mar & Apr & May & Jun & Jul & Aug & Sep \\
\hline Plan & 0 & 0 & 0 & 0 & 0 & 130 & 70 & 90 & 90 & 70 & 70 & 80 \\
\hline Actual & 0 & 0 & 0 & 0 & 0 & & & & & & & \\
\hline
\end{tabular}

FY94 Major Procurements:

Support contracts to NWC sites: $\$ 100 \mathrm{~K}$

Mechanical segregation test equipment: $\$ 100 \mathrm{~K}$

Prototype equipment for waste handling evaluations: $\$ 100 \mathrm{~K}$

Key Milestones and Markers:

\begin{tabular}{llcc} 
& Item & $\begin{array}{c}\text { Scheduled } \\
\text { Date }\end{array}$ & Status \\
\hline L142-1.1 & Surrogate feeds defined & May 94 & Open \\
L142-1.2 & Initial suite of characterization equipment identified & Jun 94 & Open \\
L142-1.3 & Validation of characterization, isolation and segregation & & \\
& methods complete & Sep 94 & Open \\
L142-1.4 & Preliminary operator control station design complete & Sep 94 & Open \\
L142-1 & 90\% Preliminary Design Review & Sep 94 & Open
\end{tabular}


February 1994

\section{WBS Element: $\quad$ 1.4.3. Liquids Feed Preparation}

Task Description:

The principal objective of the Liquids Feed Preparation system is to provide for the receipt, characterization, preparation for processing and handling of homogeneous and heterogeneous liquids and solids/liquids mixtures from storage and other processes in the treatment system. This includes segregating the incoming waste stream into aqueous with Trimsol, chlorinated organic liquids, oils, scintillation cocktails and solvents. Liquids Feed Preparation provides the management, system analysis and support, design (Title I, II, III) engineering, procurement, installation of Liquids Feed Preparation equipment, Title III inspection, and acceptance test procedures (ATP). Liquids Feed Preparation includes both liquids feed preparation equipment and systems integration.

Summary of Activities:

No significant activities to report for this reporting period.

Cost Summary: $\quad$ FY94 Budget: \$400K CENRTC

\begin{tabular}{|r|r|r|r|r|r|r|r|r|r|r|r|r|}
\hline & Oct & Nov & Dec & Jan & Feb & Mar & Apr & May & Jun & Jul & Aug & Sep \\
\hline Plan & 0 & 0 & 0 & 0 & 0 & 75 & 75 & 50 & 50 & 50 & 50 & 50 \\
\hline Actual & 12 & 5 & 1 & 0 & 1 & & & & & & & \\
\hline
\end{tabular}

FY94 Major Procurements:

Support contracts to NWC sites: $\$ 50 \mathrm{~K}$

Liquid/liquid and liquid/solid separation test equipment: $\$ 80 \mathrm{~K}$

Key Milestones and Markers:

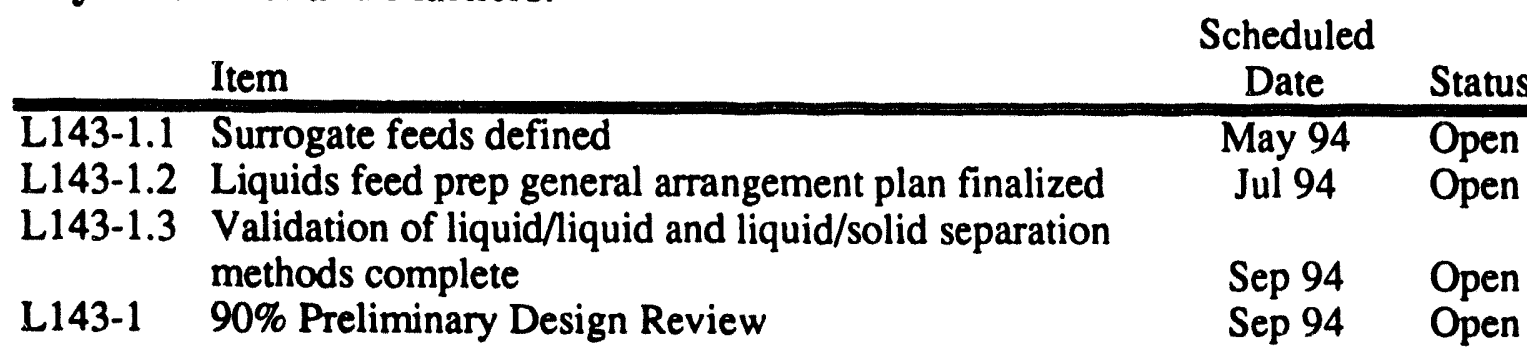




\section{February 1994}

\section{WBS Element: 1.5.1. Mediated Electrochemical Oxidation}

\section{Task Description:}

The principal objective of Mediated Electrochemical Oxidation (MEO) is to receive appropriately characterized mixed waste streams, and completely convert the organic portions to $\mathrm{CO}_{2}$ and water, to recycle acid and silver, and to remove ash containing the radioactive constituents. The MEO project element provides the management, system analysis and support, design (Title I, II, III) engineering, procurement, and installation of the viEO enuipment, Title III inspection, and acceptance test procedures (ATP) covering both equipment and system integration activities.

\section{Summary of Activities:}

During February 1994, the following activities took place in addition to the Conceptual Design effort. Experiments were conducted on the hydroxide-peroxide process to recover silver from silver chloride. The preliminary results show that the recovery yield is very strongly dependent on the hydroxide concentration. At hydroxide concentrations of 4,8 and $10.5 \mathrm{M}$, the yields were 56.95 and $98 \%$ respectively. Tests will continue to optimize this process.

The turbo-aerator to convert nitrous acid to nitric acid was removed from the bench-scale unit and is being installed in a cold flow unit to check the effect of tank volume on gas recirculation rate. A new tank made out of clear plexiglass is being fabricated, which will also serve for flow visualization studies of gas-fluid mixing.

Cost Summary: FY94 Budget: \$950K CENRTC

\begin{tabular}{|r|r|r|r|r|r|r|r|r|r|r|r|r|}
\hline & Oct & Nov & Dec & Jan & Feb & Mar & Apr & May & Jun & Jul & Aug & Sep \\
\hline Plan & 67 & 67 & 67 & 69 & 70 & 70 & 90 & 90 & 90 & 90 & 90 & 90 \\
\hline Actual & 57 & 56 & 70 & 54 & 47 & & & & & & & \\
\hline
\end{tabular}

FY94 Major Procurements:

None

Key Milestones and Markers:

\begin{tabular}{llcl} 
& Item & $\begin{array}{c}\text { Scheduled } \\
\text { Date }\end{array}$ & Status \\
\hline L151-1.1 & $\begin{array}{l}\text { Complete tests on turbo-aerator for nitrous acid } \\
\text { acid conversion }\end{array}$ & Mar 94 & In Process \\
L151-1.2 & Initiate steady-state flow and chemistry balance tests & Apr 94 & Open \\
L151-2.1 & Preliminary Process Flow Diagram & Jun 94 & Open \\
L151-1.3 & Initiate instrumentation and control system tests & Jul 94 & Open \\
L151-2.2 & Preliminary Equipment Layout & Sep 94 & Open \\
L151-1.4 & Complete tests for silver recovery & Sep 94 & In progress \\
L151-1 & Engineering characterization tests complete & Sep 94 & Open \\
L151-2 & 90\% Preliminary Design Review & Sep 94 & Open
\end{tabular}


WBS Element: $\quad$ 1.5.2. Molten Salt Oxidation

Task Description:

The principal objectives of Molten Salt Oxidation (MSO) are to receive appropriately characterized mixed waste streams and completely convert the organic portions to $\mathrm{CO}_{2}$ and water, to remove ash containing the radioactive constituents, and to recycle/process the spent salt. The MSO project element provides the management, system analysis and support, design (Title I, II, III) engineering, procurement, and installation of the MEO equipment, Title III inspection, and acceptance test procedures (ATP) covering both equipment and system integration activities.

\section{Summary of Activities:}

Engineering development needs and action plans were identified. The initial arrangement of process equipment and a vendor survey for the applicability of commercial components were continued.

Cost Summary: FY94 Budget: \$1260K CENRTC

\begin{tabular}{|r|r|r|r|r|r|r|r|r|r|r|r|r|}
\hline & Oct & Nov & Dec & Jan & Feb & Mar & Apr & May & Jun & Jul & Aug & Sep \\
\hline Plan & 29 & 15 & 17 & 22 & 25 & 24 & 34 & 34 & 56 & 83 & 431 & 490 \\
\hline Actual & 16 & 12 & 6 & 18 & 22 & & & & & & & \\
\hline
\end{tabular}

FY94 Major Procurements:

Contract for MSO system definitive design: $\$ 750 \mathrm{~K}$

Key Milestones and Markers:

\begin{tabular}{llcl} 
& Item & $\begin{array}{c}\text { Scheduled } \\
\text { Date }\end{array}$ & Status \\
\hline L152-1 & Complete bench-scale rubber destruction tests & Dec 93 & Complete \\
L152-2.1 & Advertise in the CBD & Apr 94 & In Process \\
L152-2.2 & Complete Specification & May 94 & Open \\
L152-3.1 & Preliminary Process Flow Diagram complete & Jun 94 & Open \\
L152-2.3 & Select industrial partner & Jul 94 & Open \\
L152-2 & Award contract & Aug 94 & Open \\
L152-3.2 & Initiate Preliminary Design & Aug 94 & Open \\
L152-3 & 30\% Preliminary Design Review & Sep 94 & Open
\end{tabular}


February 1994

\section{WBS Element: $\quad$ 1.5.3. Wet Oxidation}

\section{Task Description:}

The principal objective of Wet Oxidation (WOX) is to demonstrate treatment of organic mixed wastes using a wet oxidation process to convert the organic portions to $\mathrm{CO}_{2}$, water, and inorganic ions, leaving ash, salts, metals, and radionuclides in a residual solution/slurry. The WOX project element provides the management, system analysis and support, design (Title I, II, III) engineering, procurement, and installation of the WOX equipment, Title III inspection, and acceptance test procedures (ATP) covering both equipment and system integration activities.

\section{Summary of Activities:}

Experiments providing engineering data on dispersion of waste in the aqueous wet oxidation system were concluded. An in-bath mixer/blender is the recommended approach for finely dispersing cellulosics (shredded paper and cloth). Such a mixer also works well for dispersing solvents and oils. An additional circulating flow loop through a homogenizer may be included to predisperse the liquid feed stream and maintain lower liquid dispersion particle sizes.

Cost Summary: FY94 Budget: \$560K CENRTC

(NOTE: revised actual costs reflect revised cost data.)

\begin{tabular}{|r|r|r|r|r|r|r|r|r|r|r|r|r|}
\hline & Oct & Nov & Dec & Jan & Feb & Mar & Apr & May & Jun & Jul & Aug & Sep \\
\hline Plan & 7 & 7 & 7 & 7 & 16 & 32 & 76 & 56 & 60 & 67 & 165 & 60 \\
\hline Actual & 21 & 8 & 5 & 10 & 6 & & & & & & & \\
\hline
\end{tabular}

FY94 Major Procurements:

Treatability Tests, if commissioned from vendor (incl. analytical costs): $\$ 90 \mathrm{~K}$

Dispersion test equipment: $\$ 30 \mathrm{~K}$

Key Milestones and Markers:

\begin{tabular}{llcc} 
& Item & $\begin{array}{c}\text { Scheduled } \\
\text { Date }\end{array}$ & Status \\
\hline L153-1.1 & Advertise in the CBD & Apr 94 & Open \\
L153-2.1 & Dispersion system test and design complete & May 94 & Open \\
L153-2.2 & Preliminary treatability tests complete & Jun 94 & Open \\
L153-1.2 & Issue RFQ for treatment unit w/ completed specification & Jun 94 & Open \\
L153-2.3 & Preliminary Process Flow Diagram complete & Jun 94 & Open \\
L153-2.4 & Preliminary P\&ID for Support System complete & Jul 94 & Open \\
L153-1 & Award contract & Sep 94 & Open \\
L153-2 & 30\% Preliminary Design Review & Sep 94 & Open
\end{tabular}




\section{WBS Element: $\quad$ 1.5.4. Ultraviolet Photolysis}

Task Description:

The principal objective of Ultraviolet Photolysis (UVP) is to demonstrate ultraviolet-driven treatment of the hazardous and toxic organic constituents in the condensate from the Wet Oxidation process (WBS 1.5.3) to produce a sewerable water stream The UVP project element provides the management, system analysis and support, design (Title I, II, III) engineering, procurement, and installation of the UVP equipment, Title III inspection, and acceptance test procedures (ATP) covering both equipment and system integration activities.

Summary of Activities:

No activities for this reporting period.

Cost Summary: FY94 Budget: \$300K CENRTC

(NOTE: revised actual costs reflect revised cost data.)

\begin{tabular}{|r|r|r|r|r|r|r|r|r|r|r|r|r|}
\hline & Oct & Nov & Dec & Jan & Feb & Mar & Apr & May & Jun & Jul & Aug & Sep \\
\hline Plan & 2 & 2 & 2 & 5 & 6 & 12 & 26 & 33 & 99 & 42 & 36 & 35 \\
\hline Actual & 3 & 3 & 2 & -2 & 0 & & & & & & & \\
\hline
\end{tabular}

FY94 Major Procurements:

Treatability Tests, commissioned from vendor (incl. analytical costs): $\$ 55 \mathrm{~K}$

Key Milestones and Markers:

\begin{tabular}{llcl}
\multicolumn{1}{c}{ Item } & $\begin{array}{c}\text { Scheduled } \\
\text { Date }\end{array}$ & Status \\
\hline L154-1 & Preliminary treatability tests complete & Jul 94 & Open \\
L154-2.1 & UVP Process Flow Diagram & Jul 94 & Open \\
L154-2.2 & P\&ID for UVP Support System & Jul 94 & Open \\
L154-2.3 & UVP equipment layout & Aug 94 & Open \\
L154-2 & UVP 90\% Preliminary Design Review & Sep 94 & Open
\end{tabular}




\section{February 1994}

\section{WBS Element: $\quad$ 1.5.5. Experimental Off-Gas}

Task Description:

The objective of the Experimental Off-Gas (XOG) treatment is to demonstrate advanced, more effective off-gas treatment technologies that minimize secondary waste. These are: improved Selective Catalytic Reduction (SCR) of $\mathrm{NO}_{\mathbf{x}}$ to nitrogen in gaseous phase, conversion of $\mathrm{NO}_{\mathbf{x}}$ to nitrogen in aqueous urea, and use of cleanable metal HEPA filters. The XOG project element provides the management, system analysis and support, design (Title I, II, III) engineering, procurement, and installation of XOG equipment, Title III inspection, and acceptance test procedures (ATP) covering both equipment and system integration activities. The XOG will be backed by the Process off-gas system representing best available control technology (BACT).

\section{Summary of Activities:}

No activities for this reporting period. Charges shown are mischarges that will be transferred.

Cost Summary: FY94 Budget: \$250K CENRTC

(NOTE: revised actual costs reflect revised cost data.)

\begin{tabular}{|r|r|r|r|r|r|r|r|r|r|r|r|r|}
\hline & Oct & Nov & Dec & Jan & Feb & Mar & Apr & May & Jun & Jul & Aug & Sep \\
\hline Plan & 5 & 5 & 5 & 12 & 22 & 32 & 28 & 29 & 30 & 29 & 27 & 26 \\
\hline Actual & 9 & 7 & 4 & 2 & 4 & & & & & & & \\
\hline
\end{tabular}

FY94 Major Procurements:

Catalyst blocks: $\$ 6 \mathrm{~K}$

gas/liquid contactor: $\$ 13 \mathrm{~K}$

gas analyzer lease: $\$ 25 \mathrm{~K}$

Key Milestones and Markers:

\begin{tabular}{llcl} 
& Item & $\begin{array}{c}\text { Scheduled } \\
\text { Date }\end{array}$ & Status \\
\hline L155-1.1 & $\begin{array}{l}\text { Fabricate prototype gas-liquid contactor for acidic urea } \\
\text { NO }_{x} \text { destruction }\end{array}$ & Jun 94 & Open \\
L155-1.2 & Complete tests on urea and SCR DeNO & Jul 94 & Open \\
L155-1 & Engineering characterization tests complete & Jul 94 & Open \\
L155-2.1 & Initiate instrumentation and control system tesi & Aug 94 & Open \\
L154-2.2 & Preliminary Equipment Layout & Sep 94 & Open \\
L155-2 & 90\% Preliminary Design Review & Sep 94 & Open
\end{tabular}


WBS Element:

1.6.1. Process Transport and Storage

Task Description:

The principal objective of the Process Transport and Storage system is to collect, transfer, deposit, store and handle containers, discrete items, dry and wet bulk materials, slurries, and liquids. Process Transport and Storage provides management, system analysis and support, design (Title I, II, and III) engineering, procurement, installation of Process Support Systems equipment, Title III inspection, and acceptance test procedures (ATP). Process Transport and Storage includes both process transport and storage equipment and systems integration.

Summary of Activities:

No activities for this reporting period.

Cost Summary: $\quad$ FY94 Budget: \$250K CENRTC

\begin{tabular}{|r|r|r|r|r|r|r|r|r|r|r|r|r|}
\hline & Oct & Nov & Dec & Jan & Feb & Mar & Apr & May & Jun & Jul & Aug & Sep \\
\hline Plan & 0 & 0 & 0 & 0 & 0 & 25 & 30 & 55 & 55 & 35 & 25 & 25 \\
\hline Actual & 0 & 0 & 0 & 0 & 0 & & & & & & & \\
\hline
\end{tabular}

FY94 Major Procurements:

Equipment for material transport interface development: \$75K

Key Milestones and Markers:

\begin{tabular}{llcl} 
& Item & $\begin{array}{c}\text { Scheduled } \\
\text { Date }\end{array}$ & Status \\
\hline L161-1.1 & Select standard transport container designs & Jun 94 & Open \\
L161-1.2 & Finalize transport handling capacity & Jul 94 & Open \\
L161-1.3 & Finalize transport equipment selection & Aug 94 & Open \\
L161-1.4 & Validation of bagless interface complete & Sep 94 & Open \\
L161-1 & 60\% Preliminary Design Review & Sep 94 & Open
\end{tabular}




\section{WBS Element: $\quad$ 1.6.2. Analytical Laboratory}

\section{Task Description:}

The principal objective of the Analytical Laboratory system is to transport and store both liquid and solid samples within the process areas. Analytical Laboratory provides the management, system analysis and support, design (Title I, II, III) engineering, procurement, installation of Analytical Lab equipment, Title III inspection, and Acceptance Test Procedures (ATP). Analytical Lab includes both analytical lab transport and storage equipment and systems integration.

\section{Summary of Activities:}

No activities for this reporting period.

Cost Summary: $\quad$ FY94 Budget: \$50K CENRTC

\begin{tabular}{|r|r|r|r|r|r|r|r|r|r|r|r|r|}
\hline & Oct & Nov & Dec & Jan & Feb & Mar & Apr & May & Jun & Jul & Aug & Sep \\
\hline Plan & 0 & 0 & 0 & 0 & 0 & 7 & 7 & 7 & 7 & 7 & 7 & 8 \\
\hline Actual & 0 & 0 & 0 & 0 & 0 & & & & & & & \\
\hline
\end{tabular}

Major Procurements:

None

Key Milestones and Markers:

\begin{tabular}{llll} 
& Item & $\begin{array}{c}\text { Scheduled } \\
\text { Date }\end{array}$ & Status \\
\hline L162-1.1 & Select standard transport container designs & Jun 94 & Open \\
L162-1.2 & Finalize transport handling capacity & Jun 94 & Open \\
L162-1.3 & Finalize transport equipment selection & Aug 94 & Open \\
L162-1 & 90\% Preliminary Design Review & Sep 94 & Open
\end{tabular}


WBS Element: $\quad$ 1.6.3. Water Treatment

Task Description:

The principal objectives of Water Treatment are to manage aqueous streams to meet discharge requirements and address future waste water management regulations that would affect an operating mixed waste treatment facility. The Water Treatment project element provides the management, system analysis and support, design (Title I, II, III), engineering, procurement, and installation of the Water Treatment equipment, Title III inspection, and acceptance test procedures (ATP) covering both equipment and system integration activities.

\section{Summary of Activities:}

No activity to report for this period.

Cost Summary: $\quad$ FY94 Budget: $\$ 150 \mathrm{k}$

\section{CENRTC}

\begin{tabular}{|r|r|r|r|r|r|r|r|r|r|r|r|r|}
\hline & Oct & Nov & Dec & Jan & Feb & Mar & Apr & May & Jun & Jul & Aug & Sep \\
\hline Plan & 0 & 0 & 0 & 0 & 0 & 11 & 11 & 21 & 25 & 23 & 31 & 28 \\
\hline Actual & 0 & 0 & 0 & 0 & 0 & & & & & & & \\
\hline
\end{tabular}

FY94 Major Procurements:

None for this reporting period.

Key Milestones and Markers:

Item

Scheduled

Date

Status

L163-1 Water Treatment Process Flow Diagram

L163-2.1 P\& ID for Water Treatment

L163-2.2 Tanks and Water Treatment Units Layout

L163-2

90\% Preliminary Design Review

Jun 94

Open

Jul 94

Open

Aug 94

Open

Sep 94

Open 


\section{WBS Element: 1.6.4. Final Forms}

\section{Task Description:}

The Final Forms task will immobilize the residues from treatment of the mixed waste input streams. The waste form for primary treatment residues will be a high durability ceramic. Final Forms will also condition the wastes resulting from secondary support processes that are integral to the primary treatment processes.

\section{Summary of Activities:}

Studies of ceramic waste forms simulating residues from the primary treatments are continuing. Matters under investigation inclide (a) the distribution of trace RCRA elements among the phases of the ceramic; (b) adjustment of the relative amounts of the phases by changing the overall composition; (c) the effects of increasing the particle size of the starting materials; (d) the effects of using less reactive starting materials (e.g., alumina and quartz instead of kaolin), because the phase make-up of the ashes from the primary processes is uncertain; and (e) the use of fluxing agents. The leaching system is undergoing minor redesign.

Conceptual design of the system is continuing. Equipment choices are becoming clear, the main exception being the type of comminution mill to be used. It is now anticipated that the drying, calcining and granulating steps will be combined in a single rotary unit, which eases the containment problem. The used automatic press (cf. 1/94 report, "Summary of Activities") will not be used, because an alternate design provides far better containment of hazardous powders.

Cost Summary: FY94 Budget: \$550K CENRTC

(NOTE: revised actual costs reflect revised cost data.)

\begin{tabular}{|r|r|r|r|r|r|r|r|r|r|r|r|r|}
\hline & Oct & Nov & Dec & Jan & Feb & Mar & Apr & May & Jun & Jul & Aug & Sep \\
\hline Plan & 18 & 9 & 25 & 27 & 31 & 29 & 31 & 44 & 114 & 109 & 61 & 52 \\
\hline Actual & 18 & 9 & 19 & 38 & 36 & & & & & & & \\
\hline
\end{tabular}

FY94 Major Procurements:

Polymer immobilization evaluation for $\mathrm{NaCl}$ wastes: $\$ 20 \mathrm{~K}$

Blender/granular (trial unit): $\$ 20 \mathrm{~K}$

Furnace (trial unit): $\$ 20 \mathrm{~K}$

Rotary calciner (trial unit): $\$ 20 \mathrm{~K}$

Key Milestones and Markers:

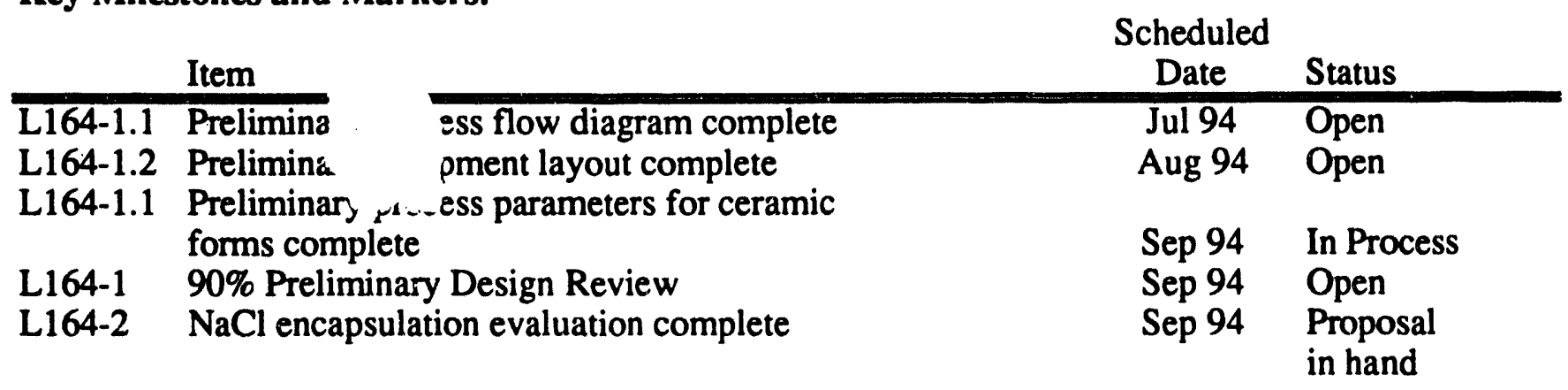


WBS Element:

1.6.5. Supervisory Instrumentation and Control

Task Description:

Instrumentation and Control (I\&C) systems will provide and integrate controls to develop, demonstrate, test, and evaluate mixed waste destruction technologies in a safe, environmentally acceptable, reliable, and cost-effective manner. I\&C systems provide the management, system analysis and support, design (Title I, II, III) engineering, procurement, equipment installation, Title III inspection, and acceptance test procedures (ATP) covering equipment and system integration activities for Central Monitoring and Control, Safety Control Systems, Standard Process I\&C, Analytical Laboratory I\&C, and intercom communication, surveillance CCTV, and telepresence systems.

\section{Summary of Activities:}

- Continued identification of system interfaces, requirements, and criteria. Continued compilation of an I\&C Plan Task summary modeled on the Project Plan Task Summary.

- Completed conceptual design activities for most Control System subsystem elements including intercom communications and CCTV surveillance.

- Continued evaluation of front-end-processors (FEP). Arranged vendor demonstrations for Modicon, Seimens/Texas Instrument.

- Continued evaluation of supervisory control systems (DCS and SCADA). Arranged vendor demonstration for WonderWare and ICOM. Had on-site discussions with Hewlett-Packard in regards to RTAP.

- Continued evaluation of work-cell controllers .

- Continued General Arrangement Plan development activities. Completed conceptual design of the Equipment Room and Control Room using the B494 80\% CDR floor plan.

Cost Summary: FY94 Budget: \$1200K CENRTC

\begin{tabular}{|r|r|r|r|r|r|r|r|r|r|r|r|r|}
\hline & Oct & Nov & Dec & Jan & Feb & Mar & Apr & May & Jun & Jul & Aug & Sep \\
\hline Plan & 20 & 20 & 20 & 35 & 55 & 70 & 90 & 315 & 90 & 140 & 170 & 175 \\
\hline Actual & 19 & 21 & 25 & 11 & 22 & & & & & & & \\
\hline
\end{tabular}

FY94 Major Procurements:

Process Control System front-end-processor hardware/software, fast prototype: $\$ 45 \mathrm{~K}$ Supervisory Control System hardware/software, fast prototype components: \$135K Handling system open architecture controller, fast prototype components: $\$ 30 \mathrm{~K}$ Telerobotics platform, fast prototype components: $\$ 60 \mathrm{~K}$ Teleoperator controller, fast prototype components: $\$ 60 \mathrm{~K}$ 
Key Milestones and Markers:

Item

Scheduled

Date Status

L165-1.1 General arrangement plan complete Mar 94 Open

L165-1.2 Process Control System FEP hardware/software selected Apr 94 Open L165-1.3 Supervisory Control System hardware/software selected Apr 94 Open L165-1.4 Handling Systems open architecture controller selected Jul 94 L165-1.5 Analytical laboratory LIMS selected

L165-1.6 Telerobotics platform selected

L165-1.7 Teleoperator controller selected Jul 94 Open Aug 94 Open

L165-1 90\% Preliminary Design Review

Sep 94

Open

Sep 94

Open

Open 

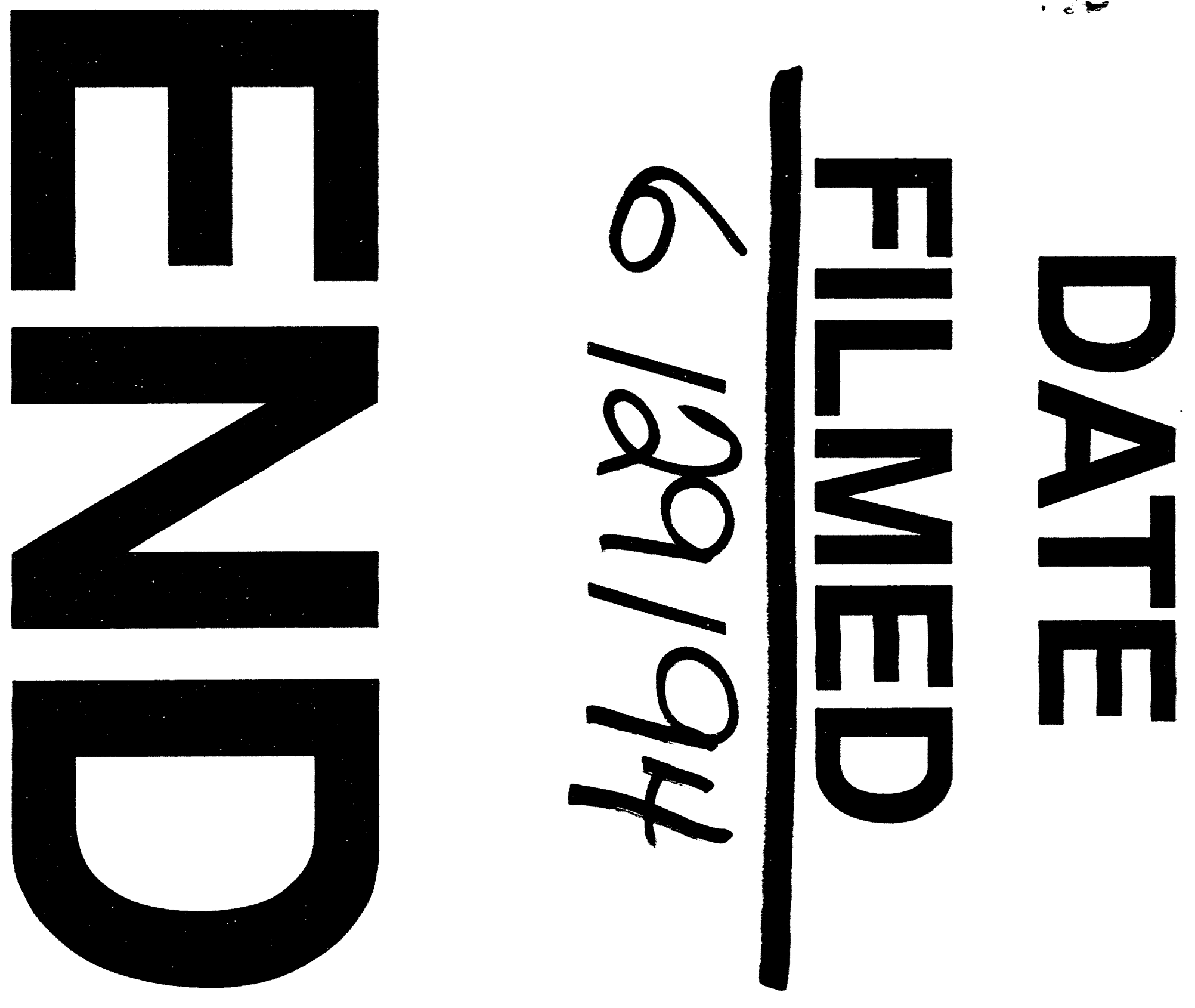
